\title{
Carbon dioxide emission from Katanuma volcanic lake, Japan
}

\author{
Pedro A. Hernández ${ }^{1,2}$, Toshiya Mori ${ }^{3}$, Eleazar Padrón ${ }^{1,2}$, Hirochika Sumino ${ }^{3}$, and Nemesio Pérez ${ }^{1,2}$ \\ ${ }^{1}$ Environmental Research Division, ITER, 38611 Granadilla de Abona, Tenerife, Canary Islands, Spain \\ ${ }^{2}$ Instituto Volcanológico de Canarias, INVOLCAN, Antiguo Hotel Taoro, Parque Taoro 22, 38400 , \\ Puerto de La Cruz, Tenerife, Canary Islands, Spain \\ ${ }^{3}$ Geochemical Research Center, Graduate School of Science, The University of Tokyo, Hongo, Bunkyo-Ku 113-0033, Tokyo, Japan
}

(Received October 21, 2010; Revised June 21, 2011; Accepted June 22, 2011; Online published February 14, 2012)

\begin{abstract}
We report herein the first results of a $\mathrm{CO}_{2}$ efflux survey carried out at Katanuma volcanic lake, Japan. A total of $110 \mathrm{CO}_{2}$ efflux measurements were undertaken at the lake by means of the floating accumulation chamber method during August 2010 to estimate the total $\mathrm{CO}_{2}$ output from the studied area. Two different mechanisms of degassing were observed during the survey; (1) diffusion through the water-air interface and (2) bubbling. $\mathrm{CO}_{2}$ efflux values ranged from 0.5 up to $322 \mathrm{~g} \mathrm{~m}^{-2} \mathrm{~d}^{-1}$. In addition, the probability graph was used to distinguish the existence of different geochemical populations in the measured values. Sequential Gaussian Simulation was used to construct a map of $\mathrm{CO}_{2}$ efflux from 200 simulations and to compute the total $\mathrm{CO}_{2}$ diffuse emission at the studied area, i.e., $17 \pm 0.6 \mathrm{t} \mathrm{d}^{-1}$.
\end{abstract}

Key words: Diffuse $\mathrm{CO}_{2}$ degassing, volcanic lake, Katanuma, Naruko.

\section{Introduction}

During the last two decades, studies of the spatial distribution of soil $\mathrm{CO}_{2}$ efflux has become an ideal geochemical tool for monitoring volcanic activity (Hernández et al., 2001a, b, 2006; Granieri et al., 2006; Pérez et al., 2011). Several authors have demonstrated that continuous monitoring of $\mathrm{CO}_{2}$ efflux provides important information for volcanic surveillance and seismotectonic monitoring (Salazar et al., 2002; Carapezza et al., 2004; Pérez et al., 2006). Other studies have shown that diffuse $\mathrm{CO}_{2}$ emissions from active volcanoes are of the same order of magnitude as the $\mathrm{CO}_{2}$ released by visible emanations (plumes, fumaroles, etc), pointing out the importance of estimating the total diffuse $\mathrm{CO}_{2}$ output from volcanic areas (Baubron et al., 1990; Allard et al., 1991; Hernández et al., 1998, 2001a; Salazar et al., 2001). Since the rate of diffuse $\mathrm{CO}_{2}$ emission can increase greatly before the occurrence of a volcanic eruption (Hernández et al., 2001a; Carapezza et al., 2004), it is very important to map surface $\mathrm{CO}_{2}$ efflux anomalies and to estimate the total output of this gas regularly in order to have a better understanding of on-going volcanic processes (Salazar et al., 2001).

During the last years, several studies have focused on $\mathrm{CO}_{2}$ emission from volcanic lakes. Volcanic lakes are generally formed by one of three mechanisms: 1) explosive excavation (crater lakes), 2) collapse of volcanic edifices (caldera lakes), and 3) blockage of common waterways (rivers, streams) by mudflows, lava flows or ash (http://www.wesleyan.edu/ees/JCV/vloverview.html). After the gas disasters at lakes Monoun (1984) and Nyos

Copyright (C) The Society of Geomagnetism and Earth, Planetary and Space Sciences (SGEPSS); The Seismological Society of Japan; The Volcanological Society of Japan; The Geodetic Society of Japan; The Japanese Society for Planetary Sciences; TERRAPUB.

doi:10.5047/eps.2011.06.038
(1986), both in Cameroon (Sigurdsson et al., 1987; Sigvaldason, 1989), accumulation of $\mathrm{CO}_{2}$ in these lakes has been well known by the scientific community. This led to the recognition that volcanic lakes are hazardous (Le Guern and Sigvaldason, 1989, 1990; Evans et al., 1994; Kling et al., 2005; Kusakabe et al., 2008). Since a large amount of magmatic gases is dissolved in water, $\mathrm{CO}_{2}$ degassing from volcanic lakes should be a process to be taken into account (Pérez et al., 2011). Degassing through the lake surface occurs by bubbles (convective/advective degassing) or by diffusion through the water/air interface (Mazot and Taran, 2009). In order to measure the gas flux from crater lakes, it may be the only way to measure fluxes at the lake surface.

This work presents the first results of a $\mathrm{CO}_{2}$ efflux measurement carried out in August 2010 at Katanuma lake, Japan. The main goals of this work are: 1) to study the spatial distribution of diffuse $\mathrm{CO}_{2}$ degassing from this volcanic lake; 2) to discriminate diffusive degassing from degassing by bubbling); 3) to estimate the total output of $\mathrm{CO}_{2}$ emitted to the atmosphere from the study area.

\section{Geological Setting}

The lake Katanuma, located in northwestern Miyagi prefecture, Japan $\left(38^{\circ} 44^{\prime} \mathrm{N}, 140^{\circ} 43^{\prime} \mathrm{E}\right.$; $306 \mathrm{~m}$ above sea level) belongs to the Narugo volcanic system (Fig. 1), which is one of the 44 Holocene volcanoes in the northeastern Japan arc. According to Sakaguchi and Yamada (1988) and Soda and Yagi (1991), the activity of the Narugo volcano began with pyroclastic activity; the Nizaka pyroclastic flow (73 ka) and the Yanagizawa pyroclastic flow (45 ka). A large caldera, of about $5 \mathrm{~km}$ in diameter was formed by these paroxysmal eruptions. Lake deposits found in the caldera indicate that water filled the caldera after $45 \mathrm{ka}$. Afterwards, lava flows and lava domes were formed in the inner part of the caldera. The youngest lavas, Toyagamori, 


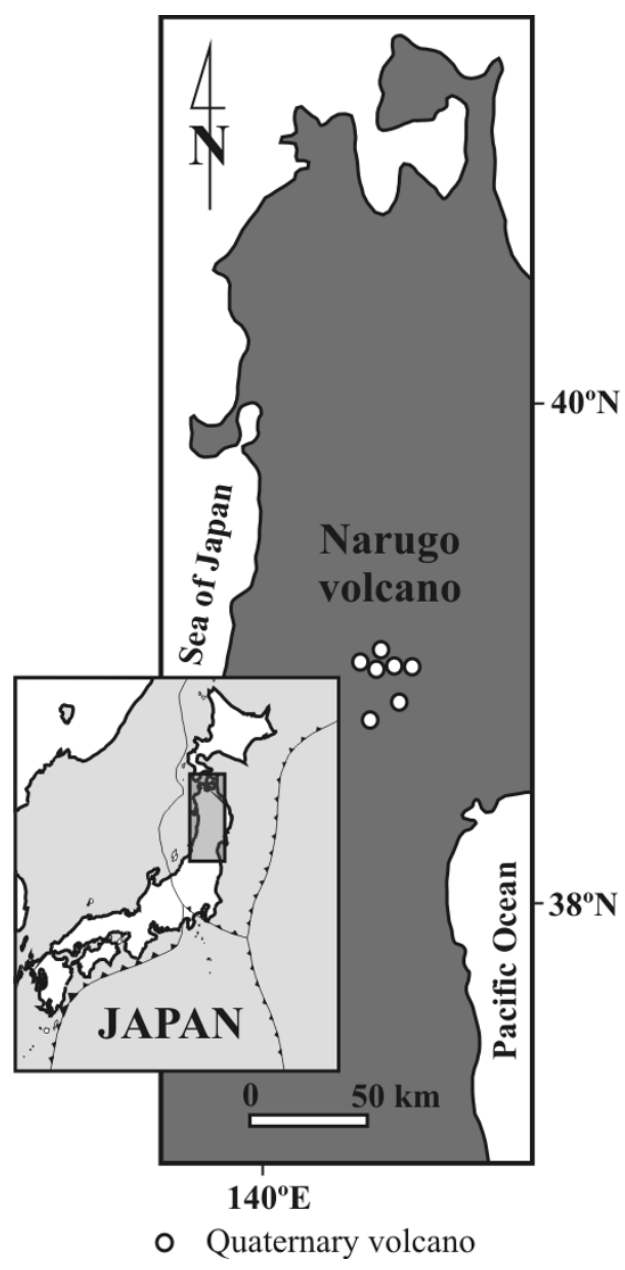

Fig. 1. Location map of Naruko volcano in Tohoku area, Japan (modified from Ban et al., 2005).

have been ${ }^{14} \mathrm{C}$ dated to be $11830 \pm 555$ years $\mathrm{BP}$ (Omoto, 1993) (Fig. 2). Observed craters were formed in the lava surface by phreatic eruptions. The only known historical eruption at Narugo occurred in 837 AD.

Katanuma is a crater lake with strong acid water $(\mathrm{pH}$ : 2.0-2.2) influenced by the volcanic fluids. The lake forms an ellipse of $462 \mathrm{~m}$ E-W length and $326 \mathrm{~m} \mathrm{~N}-\mathrm{S}$ breadth, with a $1380 \mathrm{~m}$ of shore line it has neither inflowing nor outflowing streams. The surface area is $1.26 \times 10^{5} \mathrm{~m}^{2}$ with a maximum depth of $21.3 \mathrm{~m}$ with an approximately volume of $7.48 \times 10^{5} \mathrm{~m}^{3}$. In the bottom of the lake there are some high temperature zones where hot springs flow out (Sato, 1995). These zones are located at the south and northeast basins of the lake's deepest area (Fig. 3). Volcanic gases emanating at the bottom and along the shore line of the lake dissolve in the shallow part and acidify the water by redox reactions of $\mathrm{H}_{2} \mathrm{SO}_{3}$, with heat supplied at the same time at a rate of $372 \times 10^{-6} \mathrm{cal} \mathrm{cm}^{-2} \mathrm{~s}^{-1}$ (Sato, 1995).

Lake Katanuma is dimictic and covered by ice from January to mid-March. Inverse stratification occurs under the ice cover. After turnover in March, weak stratification develops with a thermocline at a depth of 3-5 m. Stratification is generally observed from April to late August. The circulation period is from late August to December (Takagi et al., 2005).

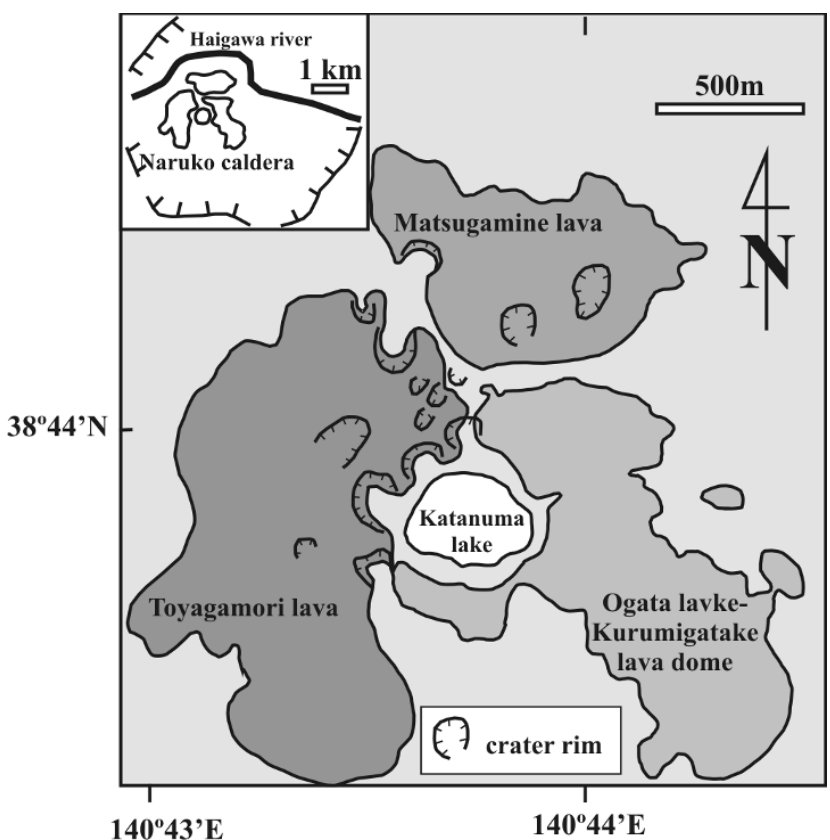

Fig. 2. Simplified geological sketch map of Naruko volcano, Japan (modified from Ban et al., 2005). Grey colors indicate different lava units.

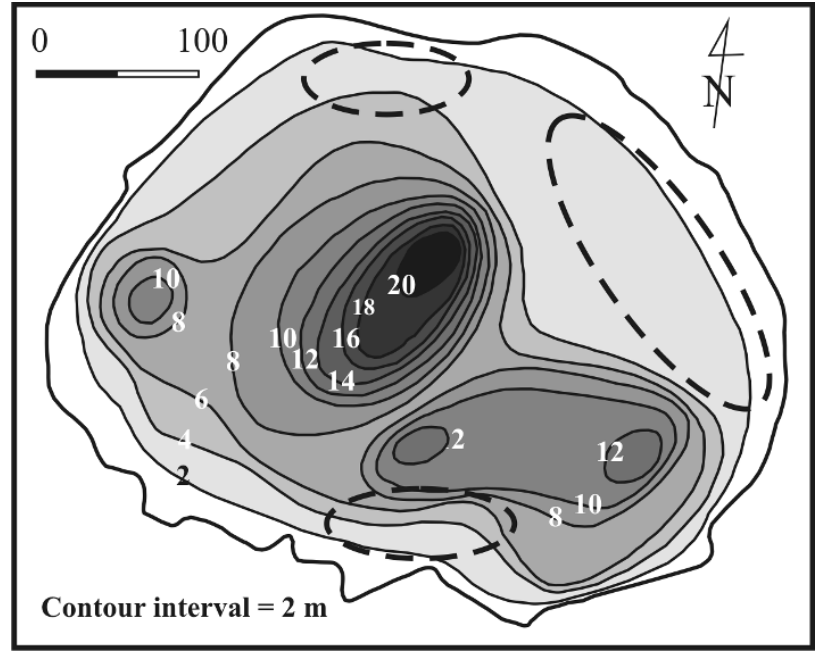

Fig. 3. Bathymetric map of Katanuma lake, Japan (modified from Takagi et al., 2005). Dashed lines indicate areas of strong bubbling gas activity.

\section{Procedures and Methods}

The $\mathrm{CO}_{2}$ efflux survey was performed during August 2010 under stable weather conditions (no wind and sunny). 110 sampling sites were selected at the surface of Katanuma lake to obtain an even distribution of the sampling points over the area of $0.14 \mathrm{~m}^{2}$ (Fig. 4). The GPS positioning of each measurement point was recorded with a resolution $\pm 5 \mathrm{~m}$. The accumulation chamber method (Parkinson, 1981; Chiodini et al., 1998) was modified in order to work on a lake by using a floating chamber (Fig. 5). Measurements of $\mathrm{CO}_{2}$ were performed in-situ by means of a portable non dispersive infrared (NDIR) $\mathrm{CO}_{2}$ analyzer (LICOR-800 system). The LICOR analyzer was interfaced to a hand size computer that runs data acquisition software. At each sampling site, water temperature, conductivity and $\mathrm{pH}$ were 


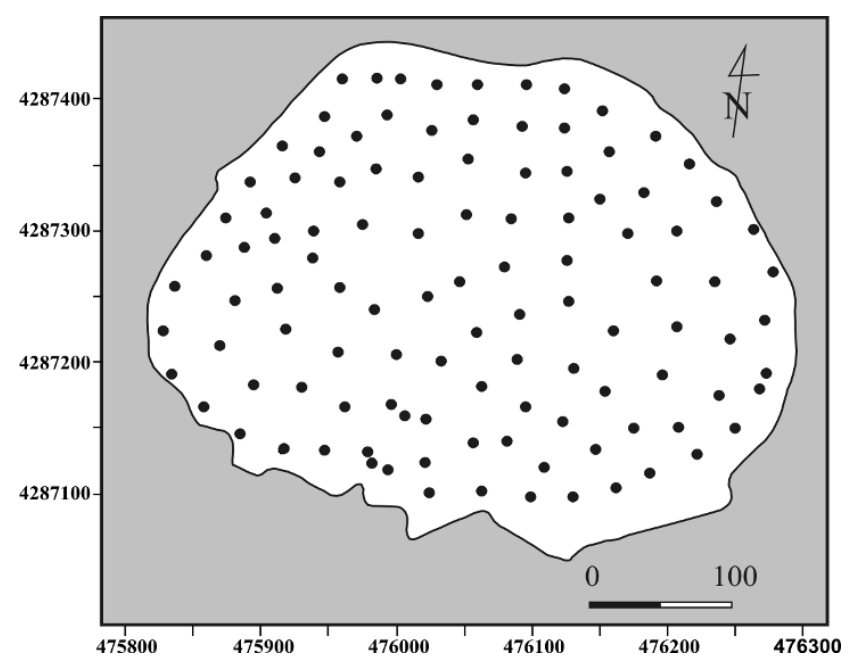

Fig. 4. Measurement sites during the study at Katanuma lake, August 2010.

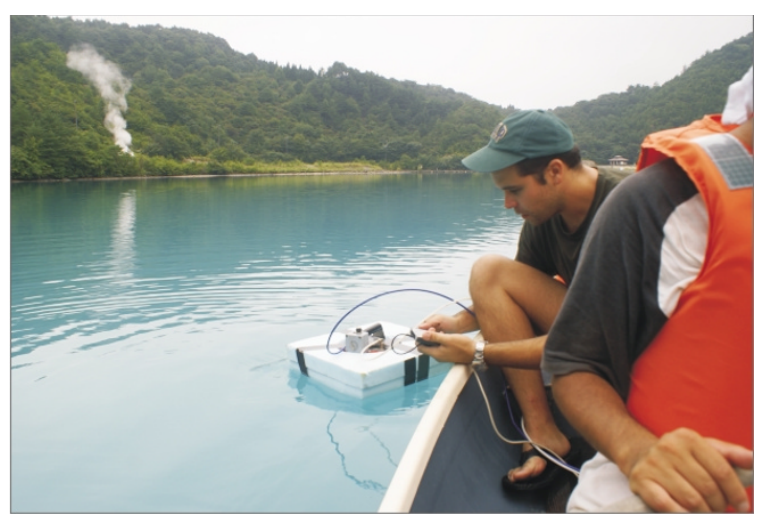

Fig. 5. Picture showing the modified accumulation chamber for $\mathrm{CO}_{2}$ efflux measurement at the Katanuma lake, Japan.

measured at a depth of $40 \mathrm{~cm}$ bellow the surface by means of a thermocouple and a portable $\mathrm{pH}$ meter. The $\mathrm{pH}$ meter was calibrated on site before the start of the survey.

Surface $\mathrm{CO}_{2}$ efflux, water temperature and water $\mathrm{pH}$ maps for Katanuma lake were constructed using Conditional sequential Gaussian simulations (sGs) provided by the sgsim program (Deutsch and Journel, 1998; Cardellini et al., 2003). In order to characterize the chemical and isotopic composition of the bubbling gas from Katanuma lake, gas samples were collected and gas composition was analyzed later in the laboratory. Gas composition was analyzed by combining a Varian CP-3800 gas chromatograph with $\mathrm{Ar}$ as the carrier gas and a Quadrupole Mass Spectrometer (QMS) model Pfeiffer Omnistar 422 . The ${ }^{13} \mathrm{C} /{ }^{12} \mathrm{C}$ ratio of $\mathrm{CO}_{2}$ (expressed as $\delta^{13} \mathrm{C}-\mathrm{CO}_{2} \%$ vs. V-PDB) was determined with a Thermo-Finnigan MAT 253 mass spectrometer at the ITER laboratory. The analytical error for $\delta^{13} \mathrm{C}$ values is $\pm 0.1 \%$. Elemental abundances of $\mathrm{He}$ and $\mathrm{Ne}$, and $\mathrm{He}$ isotope composition of the gas samples collected in a $50 \mathrm{~cm}^{3}$ lead glass bottle with high vacuum stopcocks were analyzed in the laboratory of the Geochemical Research Center, The University of Tokyo. A magnetic-sector mass spectrometer VG 5400 was used for the analysis following the methodology described by Sumino et al. (2001).

\section{Results and Discussion}

$\mathrm{CO}_{2}$ efflux values ranged between bellow the detection limit of 0.5 and $322 \mathrm{~g} \mathrm{~m}^{-2} \mathrm{~d}^{-1}$. Water temperature and $\mathrm{pH}$ ranged from 28.1 to 30.6 and 2.00 to 2.19 , respectively. Figure 6(a) shows the histogram of $\log \mathrm{CO}_{2}$ efflux values (in $\mathrm{g} \mathrm{m}^{-2} \mathrm{~d}^{-1}$ ) versus their frequency. The distribution of $\mathrm{CO}_{2}$ efflux differs from a log-normal distribution indicating that there are at least two different mechanisms of degassing through the lake surface. Following the methodology described by Sinclair (1974), a Log-normal probability graph was constructed with the $\mathrm{CO}_{2}$ efflux data (cumulative percentile frequencies against class intervals) to distinguish the presence of overlapped Log-normal geochemical populations that are recognizable by the inflection point on the curve (Fig. 6(b)). The inflection point of the curve allows us to distinguish the threshold value between the populations. The resulting probability graphs allowed to separate three geochemical populations: population I showing a mean of $21.1 \mathrm{~g} \mathrm{~m}^{-2} \mathrm{~d}^{-1}$ and represented $24.3 \%$ of the total data; population II, showing a mean of $98.2 \mathrm{~g} \mathrm{~m}^{-2} \mathrm{~d}^{-1}$ and represented $29.63 \%$ of the total data, and population III, showing a mean of $292.5 \mathrm{~g} \mathrm{~m}^{-2} \mathrm{~d}^{-1}$ and represented $3.3 \%$ of the total data. Rest of the cumulative probability corresponds to the mixing between the three identified populations. Pop-
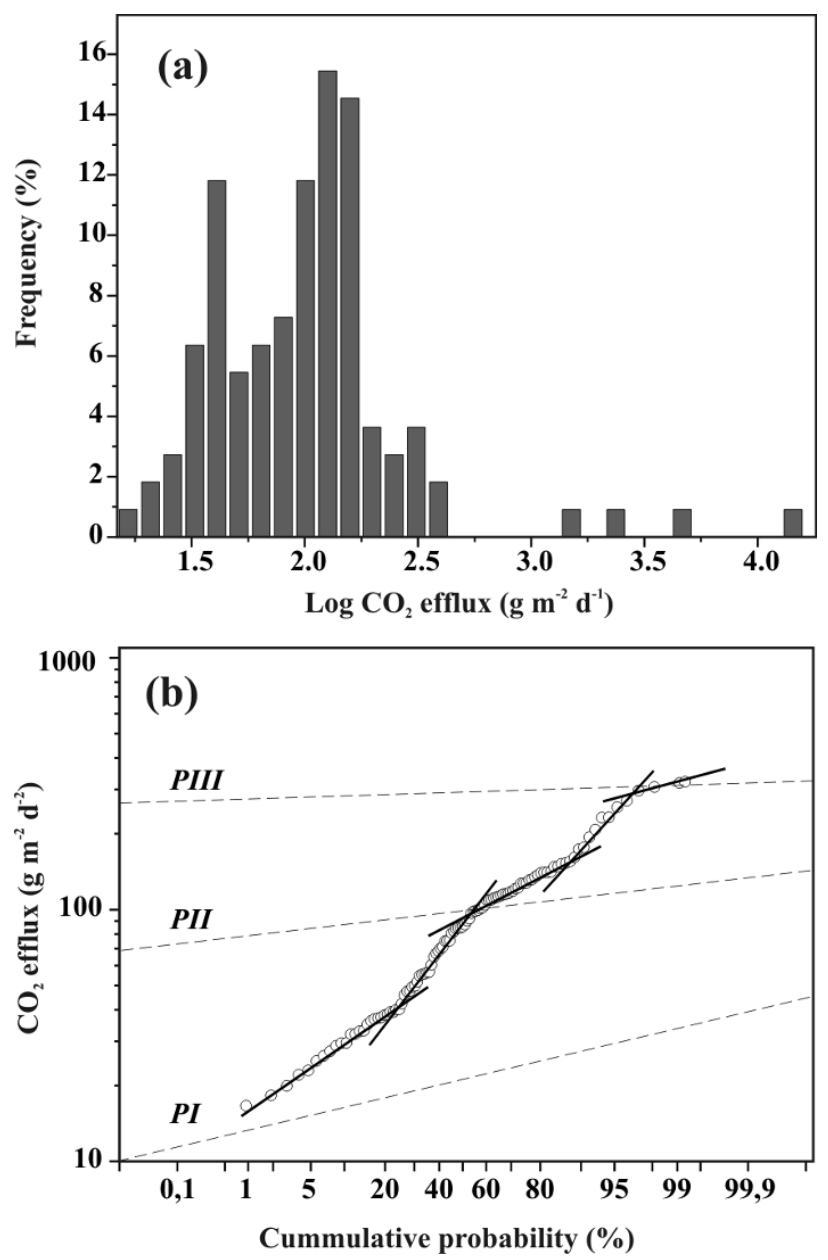

Fig. 6. Histogram (a) and probability-plot (b) of the $\mathrm{CO}_{2}$ efflux data measured at Katanuma lake. Open circles indicate the original data. Dashed lines indicate separated geochemical populations. 


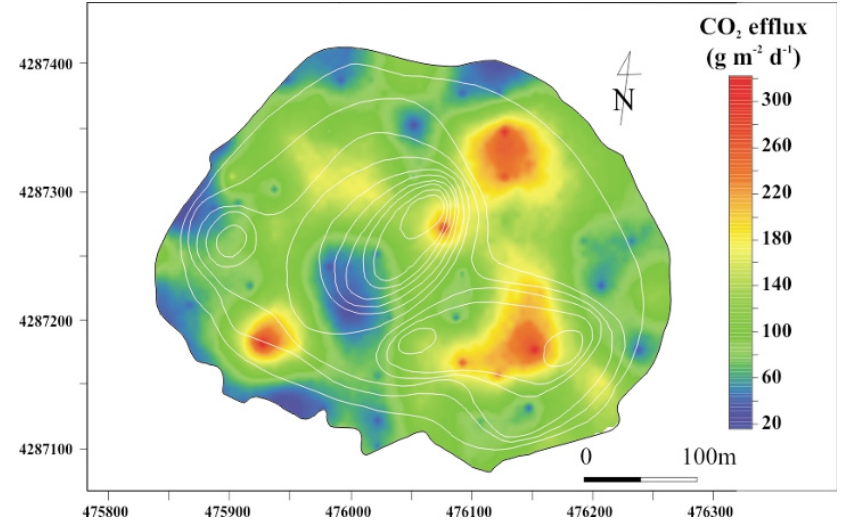

Fig. 7. Surface $\mathrm{CO}_{2}$ efflux map of Katanuma lake as a mean of 200 sequential Gaussian simulations. Bathimetric lines (white lines) are also shown in the figure. $X$ and $Y$ axis are in UTM coordinates.

ulation I represents the background values due to $\mathrm{CO}_{2}$ degassing by diffusion through the water-air interface as has been proposed by Mazot and Taran (2009) for El Chichón lake, México, and checked using the thin boundary layer model (Liss and Slater, 1974). Population II represents the $\mathrm{CO}_{2}$ efflux values from a deep source of a magmatic origin and Population III may represent gases resulting from mixing of diffuse and bubbling degassing. The existence of three different geochemical populations indicates that there are at least two different mechanisms of degassing through the lake surface, and supports the hypothesis of a deep contribution at Katanuma lake.

A total of 200 simulations were performed over a grid of 5696 squared cells $(5 \mathrm{~m} \times 5 \mathrm{~m})$ following the variogram model to construct a spatial distribution map for $\mathrm{CO}_{2}$ efflux (Fig. 7), water temperature (Fig. 8(a)) and pH (Fig. 8(b)). The experimental variograms were fitted with a spherical model with the following parameters: nugget of 0.15 and range of $45 \mathrm{~m}$. An average map was then constructed using the average of the different values simulated at each cell. Since quantification of the uncertainty of the total $\mathrm{CO}_{2}$ is an important task, the mean and standard deviation of the 200 simulated values of total $\mathrm{CO}_{2}$ output were assumed to be characteristics of the $\mathrm{CO}_{2}$ efflux and its uncertainty (Cardellini et al., 2003). Figure 7 shows the $\mathrm{CO}_{2}$ efflux distribution map at Katanuma lake based on the mean simulated total $\mathrm{CO}_{2}$ output values.

Inspection of the $\mathrm{CO}_{2}$ efflux contour map for Katanuma lake (Fig. 7) shows the existence of three anomalous areas of $\mathrm{CO}_{2}$ degassing through the lake surface without a clear emission trend. High $\mathrm{CO}_{2}$ efflux values were always measured nearby visible gas bubbling emanations and located above the deepest areas of the lake, south and northeast basins of the lake, where hot springs are thought to issue. Figure 8(a) shows water temperature contour map for Katanuma lake together with bathymetric contour lines. Even when there is a homogeneous distribution of temperature at the surface of the lake, some slight increase in temperature was observed at the southern most part of the lake. To estimate the total output of diffuse $\mathrm{CO}_{2}$ released from Katanuma lake, we considered the contribution of each cell obtained after SGS and the average of the 200 simulations
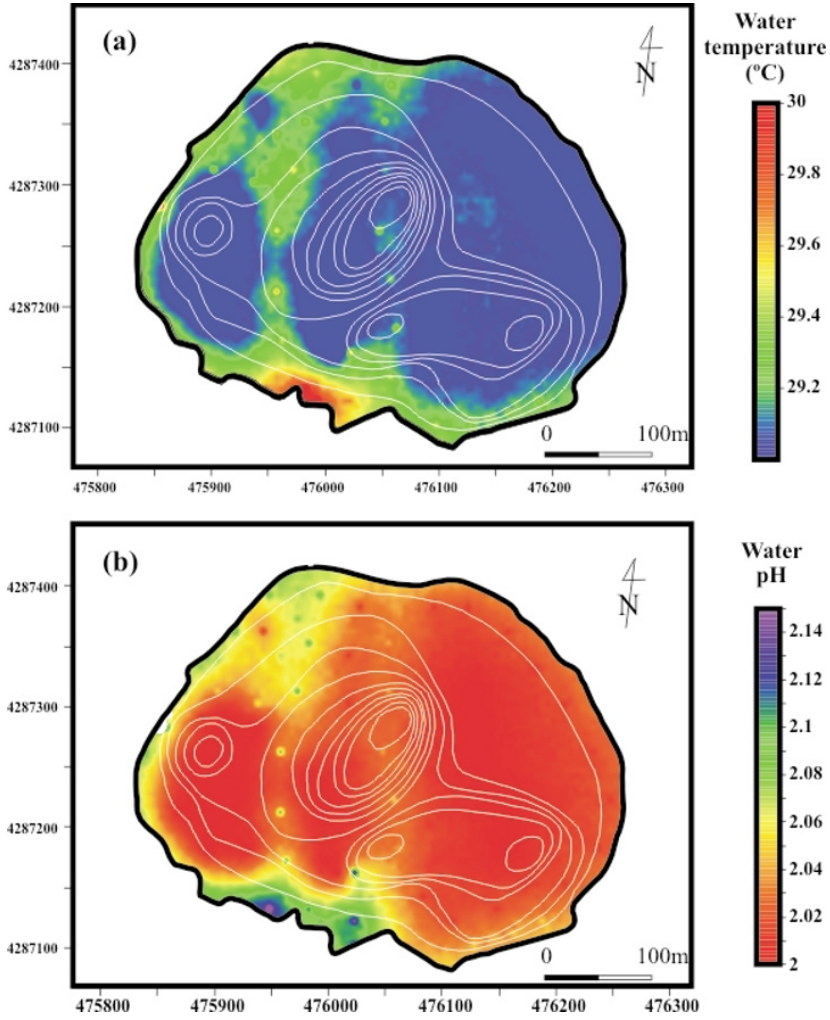

Fig. 8. (a) Surface water temperature map and (b) surface water $\mathrm{pH}$ map of Katanuma lake, both as a mean of 200 sequential Gaussian simulations for explanation). Bathimetric lines (white lines) are also shown in both figures. $X$ and $Y$ axis are in UTM coordinates.

to estimate the total output with one standard deviation as the uncertainty. The result was $17 \pm 0.6 \mathrm{t} \mathrm{d}^{-1}$ for diffuse $\mathrm{CO}_{2}$. This value is smaller than the emission rates reported for other volcanic lakes (Pérez et al., 2011). However, in order to compare individual $\mathrm{CO}_{2}$ emission of various volcanic lakes, it is important to consider the lake-type and the area. Figure 8(b) shows water $\mathrm{pH}$ contour map for Katanuma lake together with bathymetric contour lines. Most of the surface water showed an almost homogeneous acidic $\mathrm{pH}$ $(\sim 2.0)$ distribution. Katanuma, as an acid lake with an area of $1.26 \times 10^{5} \mathrm{~m}^{2}$, would have a normalized $\mathrm{CO}_{2}$ emission of $136 \mathrm{t} \mathrm{d}^{-1} \mathrm{~km}^{-2}$, a value close to that from other acid volcanic lakes in the world (Pérez et al., 2011).

As reported by Takagi et al. (2005), Katanuma lake circulates from late August to December and stratifies from April to late August. Our survey was carried out at the beginning of the monomictic circulation period (August), which significantly reduces accumulation of $\mathrm{CO}_{2}$ in the deepest part of the lake, and maximizes $\mathrm{CO}_{2}$ emission to the atmosphere. During the overturn period, when the present study was carried out, the emission of $\mathrm{CO}_{2}$ is mainly diffusive, advective and convective, showing the maximum $\mathrm{CO}_{2}$ emission in the year. In order to evaluate the $\mathrm{CO}_{2}$ emission from the bubbling spots, we measured the $\mathrm{CO}_{2}$ flux from 10 spots using the same method. We visually counted approximately 100 bubbling spots and assumed an average $\mathrm{CO}_{2}$ emission rate per bubbling spot of $14 \mathrm{~kg} \mathrm{~d}^{-1}$. Under the above assumption we estimated a total $\mathrm{CO}_{2}$ emission of $1.4 \mathrm{t} \mathrm{d}^{-1}$ from bubbling degassing. As a whole, adding diffuse and visible 
bubbling degassing, the total $\mathrm{CO}_{2}$ emission from Katanuma is estimated to be $18.4 \mathrm{t} \mathrm{d}^{-1}$.

Since water from Katanuma lake is acidic $(\mathrm{pH} \sim 2.0)$, almost all $\mathrm{CO}_{2}$ is present as dissolved $\mathrm{CO}_{2}$ and will diffuse out of the water, allowing volcanic gas fluxes to be channeled through the acid lake. Therefore, $18.4 \mathrm{t} \mathrm{d}^{-1}$ of $\mathrm{CO}_{2}$ can be considered as a deep-seated $\mathrm{CO}_{2}$ emission from Katanuma lake, because relatively high $\mathrm{CO}_{2}$ efflux values were measured during this survey including data from all geochemical populations (16.6-322 $\left.\mathrm{g} \mathrm{m}^{-2} \mathrm{~d}^{-1}\right)$.

Chemical and isotopic compositions of bubbling gases were analyzed to constrain the origin of the gases emitted through the water of Katanuma lake. Bubbling gases are clearly $\mathrm{CO}_{2}$-dominated $(72.6 \% \mathrm{~V})$ and contain $\mathrm{He}(10$ ppmV), $\mathrm{O}_{2}(4.6 \% \mathrm{~V}), \mathrm{N}_{2}(22.5 \% \mathrm{~V}), \mathrm{Ar}(0.2 \% \mathrm{~V})$ and $\mathrm{CH}_{4}$ (477 ppmV) in minor amounts. $\mathrm{N}_{2} / \mathrm{Ar}$ ratio at the Katanuma bubbling gases (112.5) is notably higher than the air ratio (83.6) and air-saturated water (ASW; 36.8), indicating an additional non-atmospheric $\mathrm{N}_{2}$ source, typical for arc volcanoes. Measured $\delta^{13} \mathrm{C}-\mathrm{CO}_{2}$ value for Katanuma bubbling gases $(-1.59 \pm 0.03 \%$ o $)$ is heavier than MORB values of $-6.5 \pm 2.5 \%$ (Pineau and Javoy, 1983; Taylor, 1986). The measured value indicates a typical isotopic composition for gases from volcanic arcs (e.g. Taylor, 1986; Marty et al., 1989; Sano and Marty, 1995; Sano and Williams, 1996; Pedroni et al., 1999; Shaw et al., 2003).

The ${ }^{3} \mathrm{He} /{ }^{4} \mathrm{He}$ ratio was also measured at $3.46 \pm 0.06 \mathrm{Ra}$, where $\mathrm{Ra}$ denotes the atmospheric ${ }^{3} \mathrm{He} /{ }^{4} \mathrm{He}$ ratio $(1.4 \times$ $10^{-6}$, Mamyrin et al., 1970). The relatively low ${ }^{4} \mathrm{He} /{ }^{20} \mathrm{Ne}$ ratio of the sample (3.73) is higher than that of the atmosphere (0.318), but still suggests atmospheric contamination of the sample. The measured ${ }^{3} \mathrm{He} /{ }^{4} \mathrm{He}$ ratio is similar to the value of $4.86 \pm 0.17 \mathrm{Ra}$ reported by Asamori et al. (2010) from the hot spring nearest to Naruko volcano. The value supports the existence of a hydrothermal system which supplies materials from underlying magma. In general, He in natural gases is composed of three components: atmospheric $\mathrm{He}$, crustal or radiogenic $\mathrm{He}$, and primordial He derived from the upper mantle. In order to estimate the mixing ratio of these components using the observed ${ }^{3} \mathrm{He} /{ }^{4} \mathrm{He}$ and ${ }^{20} \mathrm{Ne} /{ }^{4} \mathrm{He}$ ratios, we followed the methodology proposed by Sano et al. (1982). The calculated contribution for each component was $35.9 \%, 55.6 \%$ and $8.5 \%$ for MOR-type (upper mantle), crustal and air, respectively. The large contribution of the upper mantle He in Katanuma gas sample confirms active magmatic activity beneath the Naruko-Katanuma volcanic system.

Bubbling springs with lower gas/water ratios generally show higher ${ }^{3} \mathrm{He} /{ }^{4} \mathrm{He}$ ratios and consequently lower $\mathrm{CO}_{2} /{ }^{3} \mathrm{He}$ ratios (Rouwet et al., 2009). As He is less soluble in water than $\mathrm{CO}_{2}$ (Stephen and Stephen, 1963), and ${ }^{3} \mathrm{He}$ is lighter than ${ }^{4} \mathrm{He}$, gases liberated from a weakly bubbling spring tend to be enriched in ${ }^{3} \mathrm{He}$ during near-surface degassing processes and vapour separation in an aqueous hydrothermal system. This has been observed in the other volcanic areas, e.g. Tacaná volcano in Guatelama (Rouwet et al., 2009).

In order to detail deep magmatic and near-surface physical degassing processes at Katanuma lake, we have calculated the $\mathrm{CO}_{2} /{ }^{3} \mathrm{He}$ ratio of the bubbling gas. The $\mathrm{CO}_{2} /{ }^{3} \mathrm{He}$ ratio is $1.54 \times 10^{10}$, a value that fits well with the average value established for worldwide arcs $\left(1.5 \pm 1.1 \times 10^{10}\right.$; Sano and Williams, 1996). The three-component mixing model reported by Sano and Marty (1995) to calculate relative proportions of carbon sources contributing to arc magmas; MORB (M), marine limestones (L) and organic sediments $(\mathrm{S})$ was used to estimate the fraction of each $\mathrm{C}$ source for Katanuma gas sample. L source contributes $53.6 \%$, S source $3.6 \%$ and the $\mathrm{M}$ source $42.8 \%$. These values are in the same order than the reported by Sano and Marty (1995) for bubbling gas and fumarolic gas samples from Japanese volcanic areas, with limestones as the main $\mathrm{C}$ component followed by the MORB-type C. Organic sedimentary C fraction is relatively low $(3.6 \%)$, suggesting that the fumarolic feeding system beneath Katanuma lake corresponds to high temperature fumaroles.

\section{Conclusions}

$\mathrm{CO}_{2}$ efflux measurements were performed at the surface of Katanuma, a volcanic lake in Japan, by using the floating accumulation chamber method. This study allowed an estimation of $17 \pm 0.6 \mathrm{t} \mathrm{d}^{-1}$ as total diffuse $\mathrm{CO}_{2}$ emission and $\sim 1.4 \mathrm{t} \mathrm{d}^{-1}$ as $\mathrm{CO}_{2}$ emitted from bubbling spots. Chemical and isotopic analyses of bubbling gas samples from the Katanuma lake indicate a strong magmatic contribution to the gases with $\mathrm{CO}_{2}$ as the dominating gas species. To perform regular diffuse $\mathrm{CO}_{2}$ emission surveys at Katanuma lake would be important for detecting possible changes in the activity of the volcano.

Acknowledgments. This research was supported by the Japan Society for the Promotion of Science (Ref.: L10522) and the Cabildo Insular de Tenerife (Canary Islands, Spain). We are grateful to Katanuma boat rental office for their help during the field work and logistic support. The authors also want to thank M. Kusakabe and an anonymous reviewer for the constructive reviews of this manuscript as well as T. Hernan for the English reviewing.

\section{References}

Allard, P., J. Carbonelle, D. Dajlevic, J. Le Bronec, P. Morel, M. C. Robe, J. M. Maurenas, R. Faivre-Pierret, D. Martins, J. C. Sabroux, and P. Zettwoog, Eruptive and diffuse emissions of $\mathrm{CO}_{2}$ from Mount Edna, Nature, 351, 387-391, 1991.

Asamori, K., K. Umeda, Y. Ogawa, and T. Oikawa, Electrical resistivity structure and helium isotopes around Naruko volcano, northeastern Japan and its implication for the distribution of crustal magma, Int. J. Geophys., 2010, Article ID 738139, pp. 7, doi:10.1155/2010/738139, 2010.

Ban, M., K. Takahashi, T. Horie, and N. Toya, Petrogenesis of mafic inclusions in rhyolitic lavas from Narugo volcano, Northeastern Japan, J. Petrol., 1-21, doi:10.1093/petrology/egi025, 2005.

Baubron, J. C., P. Allard, and J. P. Toutain, Diffuse volcanic emissions of carbon dioxide from Vulcano Island, (Italy), Nature, 344, 51-53, 1990.

Carapezza, M. L., S. Inguaggiato, L. Brusca, and M. Longo, Geochemical precursors of the activity of an open-conduit volcano: The Stromboli 2002-2003 eruptive events, Geophys. Res. Lett., 31, L07620, doi:10.1029/2004GL019614, 2004.

Cardellini, C., G. Chiodini, and F. Frondini, Application of stochastic simulation to $\mathrm{CO}_{2}$ flux from soil: mapping and quantification of gas release, J. Geophys. Res., 108(B9), 2425, doi: 10.1029/2002JB002165, 2003.

Chiodini, G., R. Cioni, M. Guidi, B. Raco, and L. Marini, Soil $\mathrm{CO}_{2}$ flux measurements in volcanic and geothermal areas, Appl. Geochem., 13, 543-552, 1998.

Deutsch, C. V. and A. G. Journel, GSLIB: Geostatistical Software Library and Users Guide, 2nd ed., 369 pp., Oxford University Press, New York, 1998. 
Evans, W. C., L. D. White, M. L. Tuttle, G. W. Kling, G. Tanyileke, and R. L. Michel, Six years of change at Lake Nyos, Cameroon, yield clues to the past and cautions for the future, Geochem. J., 28, 139-162, 1994.

Granieri, D., M. L. Carapezza, G. Chiodini, R. Avino, S. Caliro, M. Ranaldi, T. Ricci, and L. Tarchini, Correlated increase in $\mathrm{CO}_{2}$ fumarolic content and diffuse emission from La Fossa crater (Vulcano, Italy): Evidence of volcanic unrest or increasing gas release from a stationary deep magma body?, Geophys. Res. Lett., 33, L13316, doi:10.1029/2006GL026460, 2006.

Hernández, P. A., N. M. Pérez, J. M. Salazar, S. Nakai, K. Notsu, and H. Wakita, Diffuse emissions of carbon dioxide, methane, and hellium-3 from Teide volcano, Tenerife, Canary Islands, Geophys. Res. Lett., 25, 3311-3314, 1998.

Hernández, P. A., K. Notsu, J. M. Salazar, T. Mori, G. Natale, H. Okada, G. Virgili, Y. Shimoike, M. Sato, and N. M. Pérez, Carbon dioxide degassing by advective flow from Usu volcano, Japan, Science, 292, 83-86, 2001a

Hernández, P. A., J. M. Salazar, Y. Shimoike, T. Mori, K. Notsu, and N. M. Pérez, Diffuse emission of $\mathrm{CO}_{2}$ from Miyakejima volcano, Jpn. Chem. Geol., 177, 175-185, 2001b

Hernández, P. A., K. Notsu, H. Okada, T. Mori, M. Sato, F. Barahona, and N. M. Pérez, Diffuse emission of $\mathrm{CO}_{2}$ from Showa-Shinzan, Hokkaido, Japan: A sign of volcanic dome degassing, Pure Appl. Geophys., 163, 869-881, 2006.

Kling, G. W., W. C. Evans, G. Tanyileke, M. Kusakabe, T. Ohba, Y. Yoshida, and J. V. Hell, Degassing Lakes Nyos and Monoun: Defusing certain disaster, P. Natl. Acad. Sci. USA, 102, 14185-14190, 2005.

Kusakabe, M., G. Z. Tanyileke, S. A. McCord, and S. G. Schladow, Evolution of $\mathrm{CO}_{2}$ in Lakes Monoun and Nyos, Cameroon, before and during controlled degassing, Geochem. J., 42, 93-118, 2008.

Le Guern, F. and G. E. Sigvaldason, The Lake Nyos event and natural $\mathrm{CO}_{2}$ degassing, I, J. Volcanol. Geotherm. Res., 39, 95-275, 1989.

Le Guern, F. and G. E. Sigvaldason, The Lake Nyos event and natural $\mathrm{CO}_{2}$ degassing, II, J. Volcanol. Geotherm. Res., 42, 307-404, 1990.

Liss, P. S. and P. G. Slater, Flux of gases across the air-sea interface, Nature, 247, 181-184, 1974.

Mamyrin, B. A., G. S. Anufriyev, I. L. Kamenskii, and I. N. Tolstikhin, Determination of the isotopic composition of atmospheric helium, Geochem. Int., 7, 498-505, 1970.

Marty, B., A. Jambon, and Y. Sano, Helium isotopes and $\mathrm{CO}_{2}$ in volcanic gases of Japan, Chem. Geol., 76, 25-40, 1989.

Mazot, A. and Y. Taran, $\mathrm{CO}_{2}$ flux from the volcanic lake of El Chichón (Mexico), Geofísica Int., 48(1), 73-83, 2009.

Omoto, K., Radiocarbon ages of organic materials collected from Narugo basin, Miyagi Prefecture, Quaternary Res., 32, 227-229, 1993 (in Japanese).

Parkinson, K. J., An improved method for measuring soil respiration in the field, Appl. Ecol., 18, 221-228, 1981.

Pedroni, A., K. Hammerschmidt, and H. Friedrichsen, He, Ne, Ar, and $\mathrm{C}$ isotope systematics of geothermal emanations in the Lesser Antilles Islands Arc, Geochim. Cosmochim. Acta, 63, 515-532, 1999.

Pérez, N. M., P. A. Hernández, E. Padrón, R. Cartagena, R. Olmos, F. Barahona, G. Melián, P. Salazar, and D. L. López, Anomalous diffuse $\mathrm{CO}_{2}$ emission prior to the January 2002 short-term unrest at San Miguel volcano, El Salvador, Central America, Pure Appl. Geophys., 163, 883896, 2006

Pérez, N. M., P. A. Hernández, G. Padilla, D. Nolasco, J. Barrancos, G. Melían, E. Padrón, S. Dionis, D. Calvo, F. Rodríguez, K. Notsu, T. Mori, M. Kusakabe, M. A. Arpa, P. Reniva, and M. Ibarra, Global $\mathrm{CO}_{2}$ emission from volcanic lakes, Geology, 39(3), 235-238, doi:10.1130/G31586.1, 2011.
Pineau, F. and M. Javoy, Carbon isotopes in mid ocean ridge basalts, Earth Planet. Sci. Lett., 62, 239-257, 1983.

Rouwet, D., S. Inguaggiato, Y. Taran, N. Varley, and J. A. Santiago, Chemical and isotopic compositions of thermal springs, fumaroles and bubbling gases at Tacaná Volcano (Mexico-Guatemala): implications for volcanic surveillance, Bull. Volcanol., 71(3), 319-335, doi:10.1007/s00445-008-0226-x, 2009.

Sakaguchi, K. and E. Yamada, 'The Kitagawa Dacite', pyroclastic flow deposits around the Onikobe caldera, northeast Japan, Rep. Geol. Surv. Jpn., 268, 37-59, 1988 (in Japanese with English abstract).

Salazar, J. M., P. A. Hernández, N. M. Pérez, G. Melián, J. Álvarez, F. Segura, and K. Notsu, Diffuse emissions of carbon dioxide from Cerro Negro volcano, Nicaragua, Central America, Geophys. Res. Lett., 28, 4275-4278, 2001

Salazar, J. M. L., N. M. Pérez, P. A. Hernández, T. Soriano, F. Barahona, R. Olmos, R. Cartagena, D. L. López, N. Lima, G. Melián, E. Padrón, I. Galindo, and K. Notsu, Precursory diffuse carbon dioxide degassing signatures of recent earthquakes in El salvadorSalvador, Central America, Earth Planet. Sci. Lett., 205, 81-89, 2002.

Sano, Y. and B. Marty, Origin of carbon in fumarolic gas from island arcs, Chem. Geol., 119, 265-274, 1995.

Sano, Y. and S. N. Williams, Fluxes of mantle and subducted carbon along convergent plate boundaries, Geophys. Res. Lett., 23, 2749-2752, 1996.

Sano, Y., T. Tominaga, Y. Nakamura, and H. Wakita, ${ }^{3} \mathrm{He} /{ }^{4} \mathrm{He}$ ratios of methane-rich natural gases in Japan, Geochem. J., 16, 237-245, 1982.

Sato, G., A formation mechanism of water temperature and water quality in the Lake Katanuma in the Narugo volcano, J Jpn. Soc. Water Env., 18, 829-836, 1995 (in Japanese with English summary).

Shaw, A. M., D. R. Hilton, T. P. Fischer, J. A. Walker, and G. E. Alvarado, Contrasting He-C relationships in Nicaragua and Costa Rica: insights into C cycling through subduction zones, Earth Planet. Sci. Lett., 214, 499-513, 2003.

Sigurdsson, H., J. D. Devine, F. M. Tchoua, T. S. Presser, M. K. W. Pringle, and W. C. Evans, Origin of the lethal gas burst from Lake Monoun, Cameroun, J. Volcanol. Geotherm. Res., 31, 1-16, 1987.

Sigvaldason, G. E., International Conference on Lake Nyos Disaster, Yaoundé, Cameroon 16-20 March, 1987: Conclusions and Recommendations, J. Volcanol. Geotherm. Res., 39, 97-107, 1989.

Sinclair, A. J., Selection of thresholds in geochemical data using probability graphs, J. Geochem. Explor., 3, 129-149, 1974.

Soda, T. and K. Yagi, Quaternary tephra studies in the Tohoku district northeastern Honshu, Japan, Quaternary Res., 30, 369-378, 1991 (in Japanese with English abstract).

Stephen, H. and T. Stephen, Solubilities of inorganic and organic compounds, I. Binary systems, part I. Pergamon, Oxford, 1963.

Sumino, H., K. Nagao, and K. Notsu, Highly sensitive and precise measurement of helium isotopes using a mass spectrometer with double collector system, J. Mass Spectrom. Soc. Jpn., 49(2), 61-68, 2001.

Takagi, S., E. Kikuchi, H. Doi, and S. Shikano, Swimming behaviour of Chironomus acerbiphilus larvae in Lake Katanuma, Hydrobiologia, 548(1), 153-165, doi:10.1007/s10750-005-5196-9, 2005.

Taylor, B. E., Magmatic volatiles: isotopic variation of C, H, and S, in Stable Isotopes in High Temperature Geological Processes, edited by J. W. Valley et al., Rev. Mineral., 16, 185-225, Min. Soc. Am., Washington, DC, 1986.

P. A. Hernández (e-mail: phdez@iter.es), T. Mori, E. Padrón, H. Sumino, and N. Pérez 